International Journal of Built Environment and Sustainability Published by Penerbit UTM Press, Universiti Teknologi Malaysia

IJBES 6(2)/2019, 39-49

\title{
Political Representation In Urban Public Space In Jakarta Child-Friendly Public Space (Ruang Publik Terpadu Ramah Anak - RPTRA)
}

Eka Permanasari

Department of Architecture, Faculty of Technology and Design, Universitas Pembangunan Jaya, Jalan Cendrawasih Raya B7/P Tangerang Selatan, Banten, Indonesia 15413

Email: eka.permanasari@upj.ac.id

\section{Sahid Mochtar}

Department of Architecture, Faculty of Technology and Design, Universitas Pembangunan Jaya, Jalan Cendrawasih Raya B7/P Tangerang Selatan, Banten, Indonesia 15413

Rahma Purisari

Department of Architecture, Faculty of Technology and Design, Universitas Pembangunan Jaya, Jalan Cendrawasih Raya B7/P Tangerang Selatan, Banten, Indonesia 15413

\begin{abstract}
The design of public space often embodies the power and political representation of a specific regime. As urban architecture symbolizes and establishes the identity of a regime, authorities often use a top-down approach to implement urban architectural programs. As a result, the spaces constructed often display power and identity, but lack consideration of public use. Public spaces are often exclusionary for public use. They merely stand for the representation of the authority. Accordingly, many public spaces built by the government are abandoned soon after their launch. Big ceremonies and public space displays only last a few days before these spaces are then closed to the public or appropriated for different uses. Most top-down approaches focus on the physical development, overlooking the users' inclusion in decision making. This research analyses the political representation of public space design in RPTRA Bahari located in the South Jakarta. It analyses the political reason behind the development of RPTRA in Jakarta and the way participative design approach is employed during the design process to get public engagement in public space. Therefore, it investigates how the political representation is perceived in everyday life by analysing how the public space has been used three years since its launch. Through observation and interviews, this paper interrogates the political representation in urban forms and how public spaces become an arena where the government's intentions and everyday uses meet. It concludes that a participative, bottom-up approach leads to more public use and engagement.
\end{abstract}

\section{Article History}

Received : 28 January 2019

Received in revised form : 24 March 2019

Accepted : 17 April 2019

Published Online : 30 April 2019

Keywords:

Everyday uses, political representation, public space.

Corresponding Author Contact:

eka.permanasari@upj.ac.id

DOI: $10.11113 /$ ijbes.v6.n2.351 


\section{Introduction}

For the past few years, public place making in Jakarta is only targeted to fulfil the lack of green open space in the city. Based on the article about Indonesian city planning No 26, 2007, it is stated that every city should have at least $30 \%$ of green open space. Therefore, to achieve this goal, governor tend to use top down approach in making green open spaces. By 2011, the ministry of Women empowerment and Child protection issued an article No 12 about child-friendly city indicators that every city should achieved. Here, the role of public space is not only to provide green open space, but also to enable children to have safe environment. By the end of 2014, the late Jakarta Governor Ahok in collaboration with the Indonesian Women Welfare Organization (PKK) and Community Empowerment, Women and Family Planning Bureau, planned to launch integrated child friendly public space in line with this city planning. The concept of child friendly city has long been abandoned by the former Jakarta governor and Ahok took initiative by making a child friendly community center (Ruang Publik Terpadu Ramah Anak - nicked named as RPTRA). The initial program was to launch 6 pilot projects of RPTRA by early 2015 and build another 200 RPTRAs in Jakarta by 2017 as part of his political representation. This program was his emphasis to win public support for the 2018 election, right before he was sentenced due to blasphemy cases and lost the election.

Funded by PT Pembangunan Jaya, Ahok built the initial RPTRA pilot projects in 6 municipalities to make Jakarta as the childfriendly city. Differentiating himself from the previous governor, Ahok deployed social researchers Imam Prasodjo and Eka Permanasari to be involved in the project to ensure high level of public participation in in the process of making and organizing the community centers (Permanasari, et al., 2018)

However, the process of making RPTRA receives pros and cons both from the users and from the political rivals. The pros are mainly derived from the positive intention of making public space which Jakarta is heavily lacking. Apart from that, by making RPTRA, government land assets are identified and rescued from illegal users and their function is returned for public purposes. On the other hand, the intention of involving community in every step of development to trigger community's sense of belonging towards the public space is questioned as the governor still impose top-down approach in implementing the program and limited public participation. The users are involved but their voice is not fully heard and implemented into the design.

Meanwhile, the political rival sees RPTRAs as vulnerable to be corrupted since they are funded by private company's CSR (Laksana, 2017). The total RPTRA funded by CSR is 67 and by the Regional Government budget is 223 (Mamduh, 2018). In total there are 290 RPTRAs that have been built over period 2015-2018. The political rivals also questioned the term of 'child-friendly' as whether this public space is only for children and disregard other users (Carina, 2017). Therefore, by 2018 soon after Anies Baswedan replaced Ahok, he stopped the uses term of RPTRA. To continue providing green open space, he launched a new term of public space as Taman Maju Bersama (together we moving forward park). By the end of 2018, Anies has launched 10 Taman Maju Bersama parks using the 10 billion of regional government budget (Desrianto, 2018). Here, the political representation manifested in urban forms are imminent. Architectture and urban design have been used as vehicle to symbolize power and identity (Vale, 1992).

However, the previous study in public space mainly focuses on the top-down government's approaches. Kusno (2000) and Permanasari (2010) analyse the political representation symbolized and displayed in public space (Permanasari, n.d.). The analysis is mostly about the top-down approach used by specific regime to symbolize power and identity and often disregard the community's perspective. The study of RPTRA mostly investigates what the government has done by assessing numbers of public facilities being built within the populated area (H. S. Aji, 2016) The analysis is mostly about design criteria instead of looking at the way in which people use the space after their limited inclusion during the design process (Hernowo, 2017).

This paper investigates the political representation in RPTRA Bahari as a public space located in South Jakarta. As one of the 6 RPTRA pilot projects, RPTRA Bahari has shown consistent level of public engagement since its early design concept until now. While other RPTRAs faced certain level of resistance during the design and development process, RPTRA Bahari relatively smooth in gaining public participation (Permanasari, et al., 2018). In terms of the size, RPTRA Bahari has $926 \mathrm{~m} 2$ of land and the building is two storeys with total building size $198 \mathrm{~m} 2$. The main characteristic of this RPTRA is the mini soccer field provided to cater the community needs.

The concept of public space is sometimes ambiguous in terms of political contestation. The term 'public' is questionable as it is often an exclusionary place for a large spectrum of society (Kahraman, Pak, \& Scheerlinck, March 2018). Public spaces have long been a mechanism within the capitalist mode of production. In fact, public space is used to symbolize a certain power and identity (Alsayyad, 1992). In creating public spaces, architects and urban designers are thus trapped between the authority's intentions and citizens' rights.

The idea of 'publicness' is a paradox, since the concept does not carry the real meaning of the term. Namely, the term 'public' does not really mean public, as public places are still exclusionary for others. According to Arendt (1998), to be public is a condition wherein people are heard, seen, and included in the political life (Arendt, 1998). However, this condition cannot be materialized because public spaces are always political. The idea of a public space that is open to everyone exists only in principle (Iveson, 2007). In reality, daily uses of public spaces occur within a fragmented society where interest groups compete against each other. Public spaces are the domain for struggles between the dominant, and hence public spaces are by nature counter-public. The idea of public spaces raises the question 'whose public spaces?' Even though public spaces carry the term 'public', political powers will reorganize, 
demolish, control, and militarize public spaces if necessary. Authorities tend to limit public access and strive to keep public spaces in line with the original intention behind the spaces' construction.

Public spaces are a social and physical representation of space and community. However, the term 'representation' is also ambiguous, since the word 'representative' means doing something on behalf of someone else. Representation implies both presence and absence of the represented, such that there can be decisions made on behalf of the citizen with clear instructions. However, when representatives make a decision, does it really represent the citizen? Thus, political representation starts to fail when the citizens' explicit objections are voiced.

This condition resonates with Arnstein's (1969) ladder of participation (Arnstein, 1969). Arnstein highlights a ladder of citizen participation on which eight rungs indicate citizen participation levels in public places. The first two rungs show a non-level of participation wherein government policy aims to educate participants. The third and fourth rungs (informing and consultation) show the degrees of tokenism. Citizens are allowed to speak, but they do not have the power to implement opinions. The fifth rung (placation) allows citizens to advise the government. However, citizens do not have the power to decide because the government is the power holder.

The ladder's highest levels represent the degrees of citizen power: the sixth rung (partnership) allows citizens to partner with the government. The seventh rung (delegated power) and eighth rung (citizen control) allow citizens to have majority decision making and full managerial power. Based on these classifications, we can analyse how much citizens can engage in public spaces. It can be concluded that regardless of the level of participation, public space is a tricky concept and does not necessarily include public involvement.

The purpose of urban projects is generally to show the intent of economic growth. In cities, urban spaces are used as leverage to show market-oriented economic growth that is aimed at everyone, even though profits are then exploited by the elite few. Indeed, architecture and urban design are commonly used by political regimes as a way to exercise and express their power. As a result, the development does not involve public engagement and often disregards public needs.

This condition has forced urban designers and architects to analyse public spaces' requirements for everyday uses. Urban planners and architects are challenged: they must accommodate public interests based on the idea of making a public sphere and publicly accessible spaces (Tonnelat, 2010). The public sphere deals with participative democracy while publicly accessible spaces concern the idea of individual liberty, which resonates with Lefebvre's (1996) right to the city (Mitchell, 2003).

In the 1970s, there was a global movement against this condition as to how a public space should be. Jan Gehl (1987) proposed a new approach of designing public space by including the presence of other people, stimulating activities and events. Public spaces are also a common ground for people to do everyday activities, both as routine or periodic activities (Carr, Francis, L.G, \& Stone, 1992).

Another movement is called bottom-up urbanism, where the public spaces' design should include the voice of citizens. In bottom-up urbanism, there are three forms of practices: occupy urbanism, tactical urbanism, and hybrid urbanism. Occupy urbanism includes DIY (self-organized) practices where ordinary people gather and reclaim urban spaces through various acts of communing: the collective sharing of space (Pak, 2017). Tactical Urbanism involves ordinary people that take part in shaping their environment during the design process and most importantly through the product itself. This is usually executed for short-term plans or projects. Hybrid Urbanism combines communing practices and planning (Pak, 2017).

Participation is based on the interaction between the designer and the user. It includes various other actors such as governmental institutions, political decision makers, and nongovernmental organizations. In a participative design, the public actors have power in the decision-making process in any political context. The local people are the main information source for the designers, as they can provide an understanding of the local knowledge, needs, and values that are important for the design process (Sanders, Elizabeth B-N; SonicRim, 2002). This is especially true in spatial design because users care about their living spaces. In urban design, a good, organized, and efficient public participation will foster a sense of belonging because of its unique locality.

Participation in design has several benefits for both parties and for the whole community (Dede, 2012). For users, it represents an increased sense of influence on the decision-making process and an increased awareness of the consequences. This minimizes activities such as vandalism, since there is a sense of belonging to the space. For the designer, it represents relevant and up-todate information, which generates many design ideas. Finally, for the whole society, participation benefits the community by meeting their social needs and by increasing the effective use of resources. Participative design's main purposes are to involve and to unite citizens in the decision-making process, to promote a sense of community, and to increase user satisfaction (Dede, 2012).

\section{Methodology}

To analyse the political representation and community sense of belonging in the Child-Friendly Public Space of RPTRA Bahari, three main qualitative research methods were used to gather data: observing physical traces, observing environmental behaviours, and focused interviews. The qualitative research methodology is cross examined through three various research methods to get objective analysis.

Observing physical traces involves carefully examining the physical surroundings to analyse the previous activities that may have occurred within the space (Zeisel, 2006). From these 
observations, we were able to determine the users' profiles such as their culture, affiliation, and preferences.

Observing environmental behaviour involves analysing how people use the space and how they interact with others and the environment. At the same time, it also involves examining how a setting interferes with activities. With this method, researchers can generate data about people's activities, the relationship between regulations and people's behaviours, and the uses or misuses of place (Zeisel, 2006).

These observation methods were conducted to analyse the use of RPTRA in everyday life, how people appropriate the space amidst its political insinuation and their inclusion in the public space. Observations were conducted using photography and mapping techniques that captured public activities during weekdays and weekends from the RPTRA Bahari launch until now. Observations were carried out in public spaces without interrupting activities occurring on the site. To maintain the objectivity and privacy, this paper ensures the anonymity of the interviewee and the anonymity the users of RPTRA Bahari while mapping and observing their activities.

\section{Result and Discussion}

Built in Jakarta in 2015, the RPTRA Bahari in South Gandaria district, South Jakarta is one of the city's 6 RPTRA pilot projects. Initially, the project aimed to provide Jakarta with a communal space for children. This aim was in line with the governor's plan to provide a child-friendly city for its citizens (Permanasari, Nurhidayah, \& Nugraha, 2018). Unlike the previous urban approach, Ahok wanted RPTRA to be developed by the bottom up model using participative design approach.

The participative design approach in RPTRA Bahari followed the 6 steps of the design process: social mapping, discussions about the initial design, final design, working together in building the RPTRA, and discussion about RPTRA management. The whole process took approximately 6 months during which the society was included in every step of the process.

The social mapping began when the architect, urban designer, and social researcher pictured the existing conditions on the potential site. South Gandaria district area is about 177 ha, with an approximate population of 24,783 people. The heavily populated areas have mixed building density. The district chief is very famous and active in the community engagement. Based on the site visit, there were community-based activities such as handicrafts, a reading club, traditional dancing, a children's learning forum, a creative economy, mini soccer, morning aerobics, and acoustics. The community is also involved in recycling materials and making waste recycling banks.

The next step is forming a design concept to involve the community in the participative design process. The architect and social researcher proposed the idea of a community centre that would cater to the needs of children with positive activities. Since the area is densely populated and has many buildings, the only open space belonged to the government was the proposed area is $926 \mathrm{~m} 2$. Achmad Noerzaman, the architect, explained the building's purpose and how it would operate. The community provided feedback on the types of activities they needed so that the design considered the space requirements. During the discussions, the citizens were encouraged to voice their concerns and aspirations. The architect and social researcher became the mediators who linked the citizen and the government.

Gathering people's participation allowed the citizens to speak and propose their ideas. However, the process did not guarantee that these ideas would be implemented (Permanasari, Nurhidayah, \& Nugraha, 2018). This finding correlate with Arnstein's (1969) ladder of participation in which informing and consultation become a part of a space's social production. The concept of participation is also questioned, as those who attended the forum were representatives of the citizens. Since the term 'representative' is ambiguous, a process that includes only the citizens' representatives carry multiple dimensions and the ideas of the represented may not actually have been taken into account at all.

Those that attended the meeting were mostly from the family welfare organization; this organization is a top-down organization model which places the wives of the power holder organizing the discussion. Even though public participation was encouraged, it was difficult to identify the public aspirations during the process. The participative design approach's next level was to finalize the design consultation, to build the community centre together, and to plan the activities.

The participatory design approach was a good first bottom-up step that allowed the citizens to speak and channel their aspirations to build and operate in a public space, even if the citizens' participation was somewhat limited and questionable. Regardless, the method allowed the bottom-up process to occur at the beginning of the space's production. However, the initial process should have raised more public awareness and participation; the resulting weaknesses can be examined by the everyday uses of space.

Ahok claimed that the community centres are designed to include citizens; accordingly, the public space should have citizens' activities and engagement. However, the claim on political representation in public space cannot be taken for granted. Therefore, we examined how this place is used in everyday life. The analysis compares the activities that were planned during the participatory design stage with the activities that are occurring now. The time lapse will show the activities' consistency and engagement level.

The activities that were planned before the launch were based on age classification. For instance, activities for children and teenagers included the following: sports (mini soccer, badminton), local music (angklung, traditional hadroh, marawis), drama, and learning (library) and health facilities. Activities for adults and seniors included sports (badminton, aerobics, chest), music and family welfare programmes (gardening, nutrition). The plans show the community centre 
space programming [Figure 1] where you can identify a mini soccer field that overlaps with the badminton field, a multifunction room, and a store for selling community products. The multi-function room caters different activities. The garden and fish pond are provided to cater to gardening and fish farming activities. On the second floor, there is a library, training room, youth organization room, and music room. These rooms were planned based on the citizens' requirements, on the budge, and on the space availability. Compromises between the government and the citizen were made.
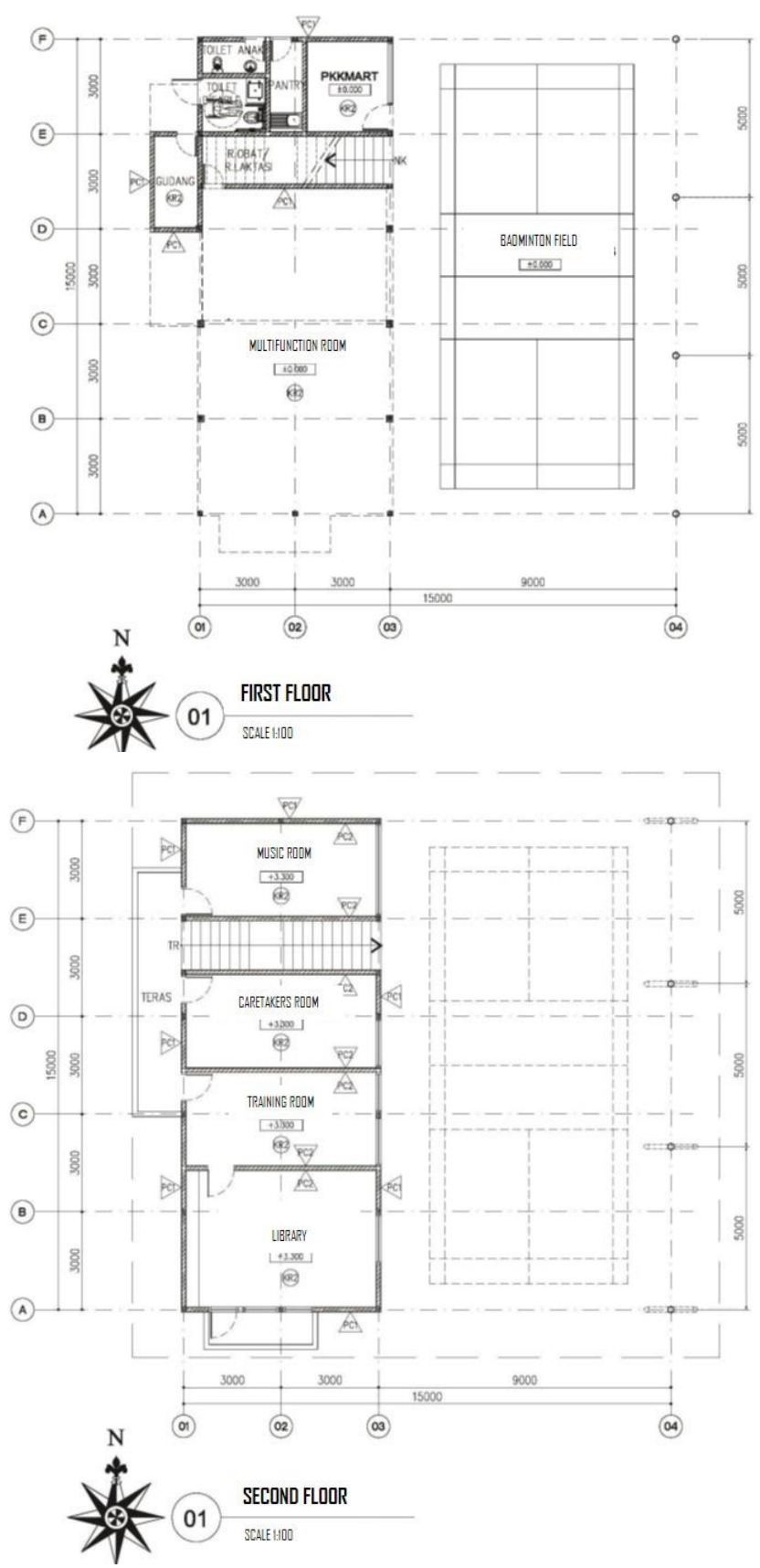

Figure 1 Floor Plan of RPTRA (Author, 2015)

The proposed activities affect the public space's design, and incorporate the authority's agenda, and citizen's aspirations. Then, to examine whether the bottom up approach has given impact to the idea of publicness, we need to evaluate how this public space is used every day. The observation was done during weekdays and weekends during three time periods (morning, midday, and afternoon) to determine the comprehensive pattern of the activities on the site. Based on the observations, there had 
been changes in the uses and space programming. The RPTRA management had replaced the youth organization room. The traditional medicinal plants garden is well looked after, but the hydroponic section is no longer intact and requires heavy maintenance. Some facilities such as the sinks are no longer in use. Other than that, the library, the common rooms, and the multi-function room are used.

To analyse the political representation insinuated in urban forms, we created a special pattern to see how people use the space. The mapping shows how this pace is used over the weekend. Overall, the RPTRA is always busy with children playing mini soccer or parents watching their toddlers. During the school holiday break, RPTRA is more crowded since children use the place as their playground. Weekday observations were taken in July 2018 during the school holiday. In the morning, children played mini soccer while others were in the playground. Parents often accompany their children or have social activities here too.

During school days, it is a different story: the RPTRA is mostly empty and only filled with smaller kids who haven't started school yet. Usually accompanied by their parents, the kids play together downstairs, read books at the library, or are in the music room. The government provided the library to educate children and the general public. Although it is called the music room, its purpose is not only to play with the traditional bamboo music tool (angklung) inside, but also to play with a box full of Lego.

By noon, the activities change into a more regular pattern. Some students from various high schools use the soccer field to practice taekwondo. Students are eager to use the RPTRA for their school activities. Neighbouring schools also use the RPTRA for their routine sports activities. For instance, PAUD Pelangi, Kindergarten Al Huriyah and Madrasah Bahari use the RPTRA on Wednesday and Friday. Students from SMK 28 Jakarta use the RPTRA for traditional dance classes. Based on the FGDs that we conducted to investigate the sense of belonging in RPTRA [Figure 2], these activities are often not found in the organizer's schedule. In fact, there are volunteers in this RPTRA such as Mrs. Maya who is willing to teach English to children pro bono. She was an English instructor at a private English training company but cares about children's education and teaches on Wednesday afternoon. The participation levels show citizen's engagement in this public space.

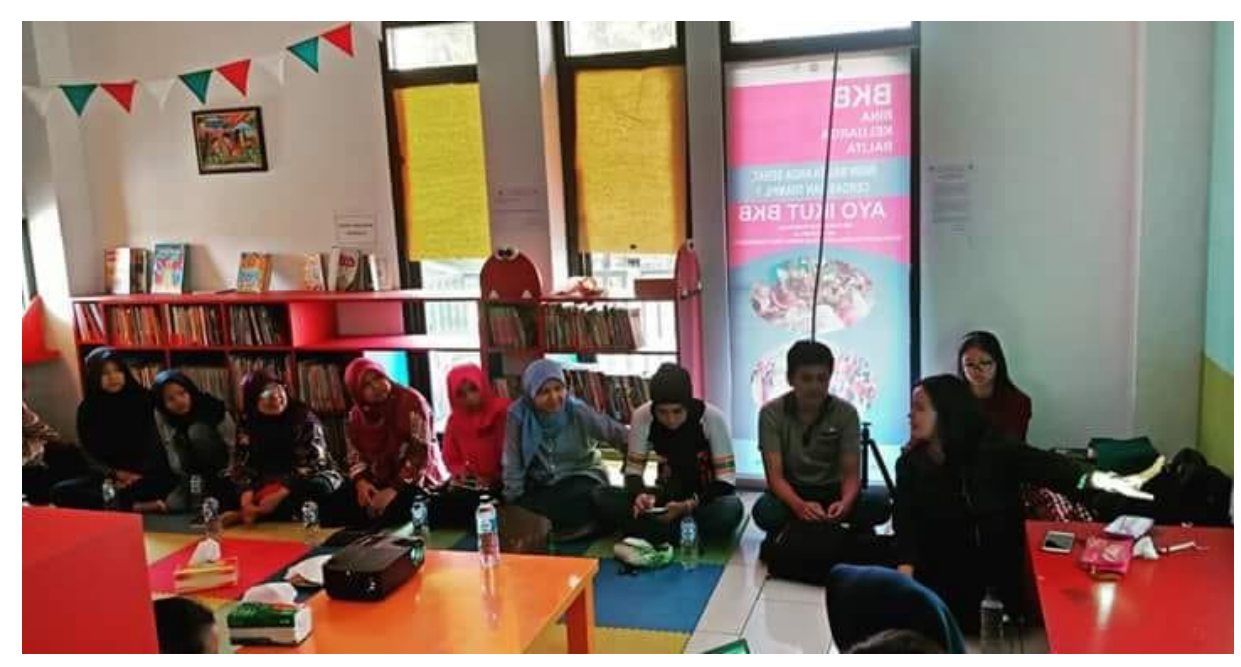

Figure 2 FGD about activities in RPTRA (Author, 2018)

RPTRA caters activities not only for those living in the surrounding area but also to surrounding schools. RPTRA has become a public space that is free to use as long as the users respect and follow the rules. However, this publicness is not completely public because there are some accessibility restrictions. For instance, smokers are not allowed to enter the site. The RPTRA closes by $6 \mathrm{pm}$, which means that the public space only operates within a certain period of time. Figure 3 shows the activities on a Tuesday morning with a few children mostly in the library. Those playing in the mini soccer field are only there for a short time because at this time the sun is already hot. The library and music room are popular spaces because they are air-conditioned. 


\section{MAPPINGRPTRABAHARIGANDARIA SELATAN \\ WEEEKDAYS TUESDAY,14 AUGUST 2018}
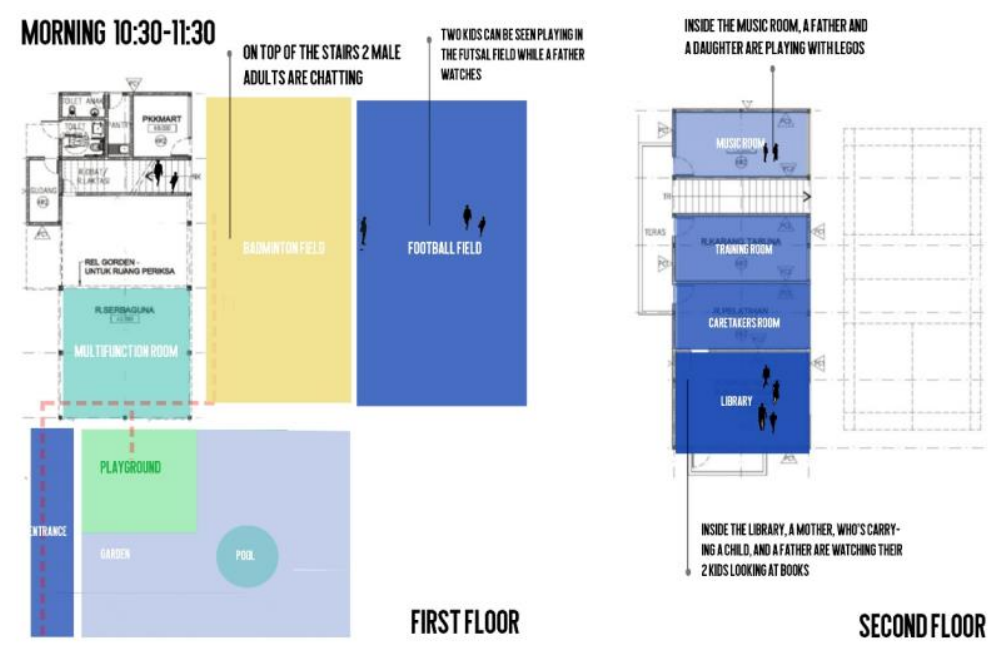

Figure 3 Mapping RPTRA weekday morning (Author, 2018)

RPTRA Bahari has more visitors on weekday afternoons. All of RPTRA's facilities are in use such as the badminton and soccer fields. Older children and teenagers play on the soccer field, while the younger children play on the badminton field. Meanwhile, other children are watching from the sides or doing other activities in the playground. Meanwhile, the multifunction room is usually being used by adults while toddlers sit and play. The RPTRA provides a communal space where children, teenagers, and parents interact with each other. The playground is filled with children taking turns using the playing equipment. The children mostly use the music room to play Lego. If we map the activities during the weekday afternoon, most activities are on the ground floor where children play mini soccer and badminton while toddlers play in the playground. Others are on the first floor and in the library [Figure 4].

\section{MAPPING RPTRA BAHARIGANDARIA SELATAN WEEKDAYS TUESDAY,3JULY 2018}
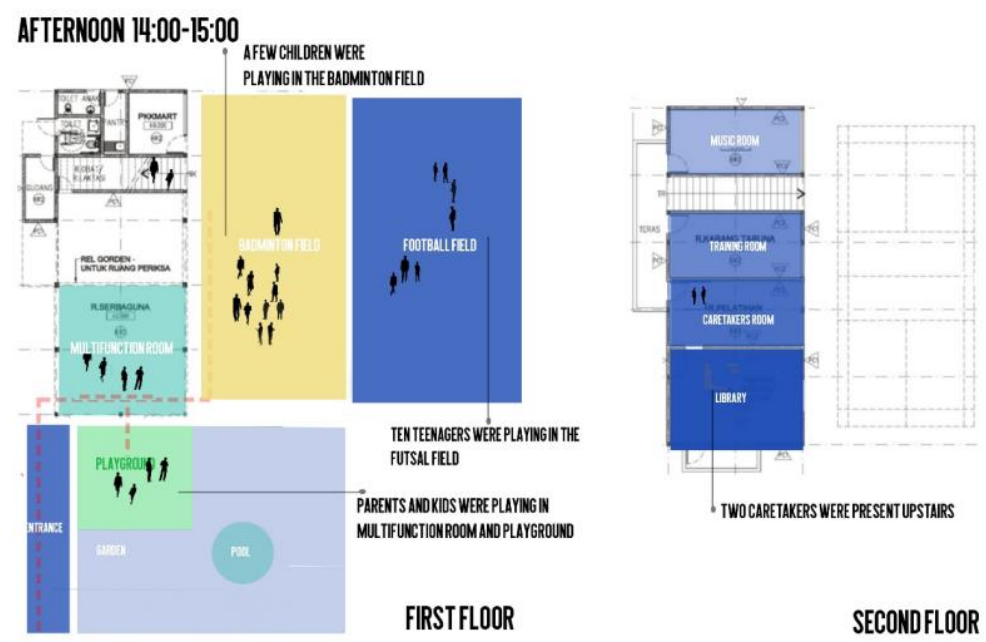

Figure 4 Mapping RPTRA weekday afternoon (Author, 2018) 
During the weekend, many use the RPTRA, like children and mothers during social gatherings (arisan) or governmental bodies implementing their policies, such as marine, agriculture, and food security bureaus that supply highly nutrient food for locals or local NGO named Kelompok Wanita Tani (Female Farmer Group). In collaboration with certain public health organizations (Alfa Omega and Obor Bakat Indonesia), RPTRA Gandaria Selatan also holds events such as free health consultations and free immunization.

Social gatherings and free health consultations only take place once a month. During normal weekends, RPTRA's multifunction room is used in a more open way. It is usually filled with mothers and nannies that are watching children, feeding them, or conversing among each other. This shows that the RPTRA brings people together, provides a safe environment for children, and encourages people to socialize amidst Jakarta's lively bustle.

On weekend mornings, kids usually use the badminton field to play soccer and for other activities such as raising flag ceremony training (Paskibra), Taekwondo, and Pencak Silat. In the image below, girls of SMA Tunas Pembangunan's Paskibra are practicing their march. Once they finished their training session, teenagers have their taekwondo and silat exercises. This place is popular because it has a roof over it, protecting people from the sun's heat.

Meanwhile, the library is in constant use: it is open from 08.00 - 18.00 during weekdays and can stay open late during holidays. Children are welcomed at the library to study or to read books. The library is also used for learning, knowledge sharing, and other educational purposes like English and math lessons. If we map the daily activities during the weekends, we can see that RPTRA is constantly in use. Children prefer to use the soccer field, playground, and library. Adults accompany their children or massage their feet around the reflection pond. Most of the RPTRA's users are children and male teenagers, while teenage girls are only present when there is a specific activity like traditional dancing [Figure 5].

\section{MAPPINGRPTRA BAHARIGANDARIA SELATAN WVEEKENDS SATURDAY,IIAUGUST 2018}

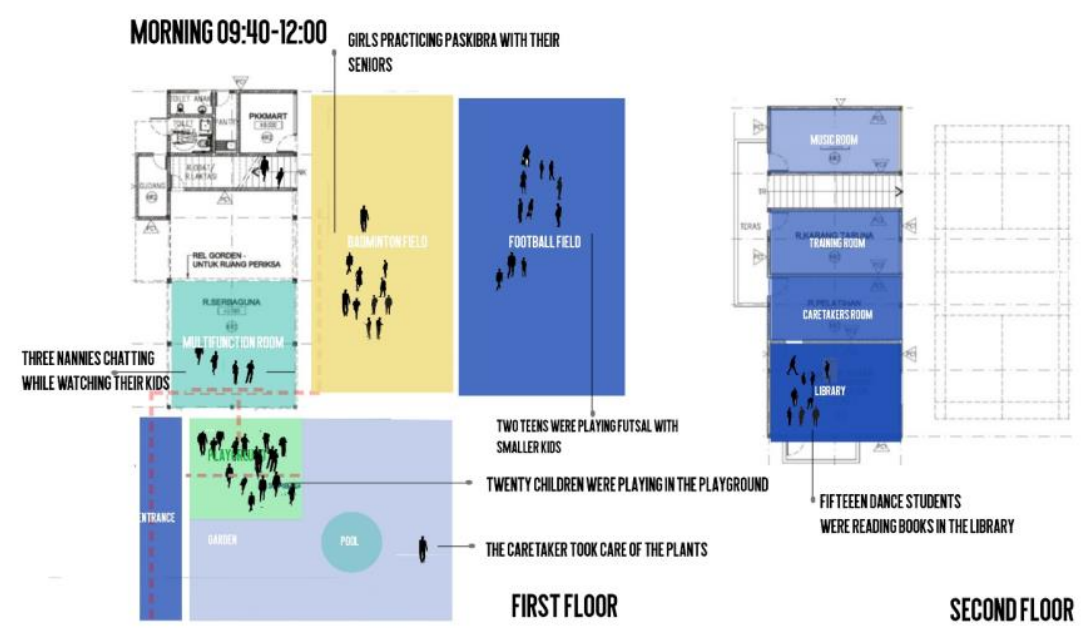

Figure 5 Mapping RPTRA weekend morning (Author, 2018)

At noon during weekends, there are not many people who visit the RPTRA. Only a few children play on the soccer field while other play in the multifunction room. Most of the rooms upstairs are empty, except for the caretaker's room. According to the caretakers, people start to come to the RPTRA after $2 \mathrm{pm}$, when the weather starts cooling down. During the weekends, some external events are organized like the Arisan Mapan. While social gatherings are in the RPTRA's multifunction room, the rest of the RPTRA is in constant use [Figure 6]. 


\section{MAPPING RPTRA BAHARIGANDARIA SELATAN \\ SATURDAY,14 APRLL 2018}

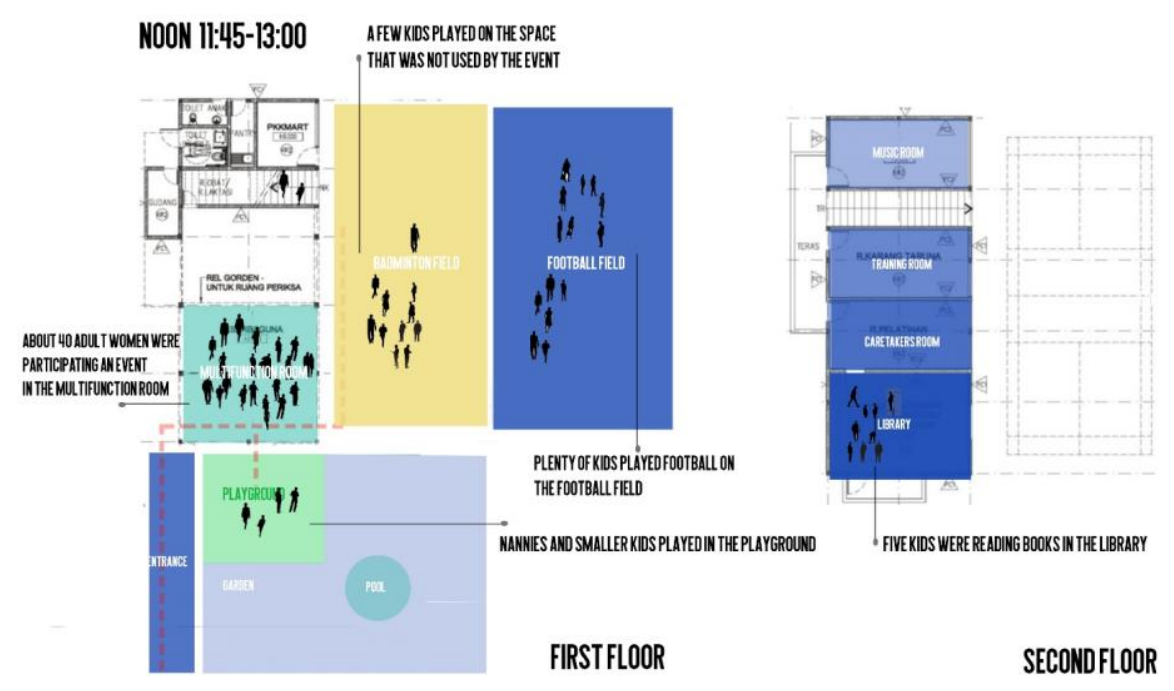

Figure 6 Mapping RPTRA weekend noon (Author, 2018)

On weekend afternoons, the RPTRA's activities pick up as the weather cools down. The multifunction room is used by girls between 12 and 14 years old use to practice Betawi's traditional dance. The instructor is from Dinas Pariwisata (Government Tourism Office) and is part of the RPTRA programmes in Jakarta. As the girls are dancing, parents and caretakers watch them with joy. During dance classes, other children are in the playground. The mini soccer and badminton fields are the most popular feature where children and teenagers play or watch along the side [Figure 7].

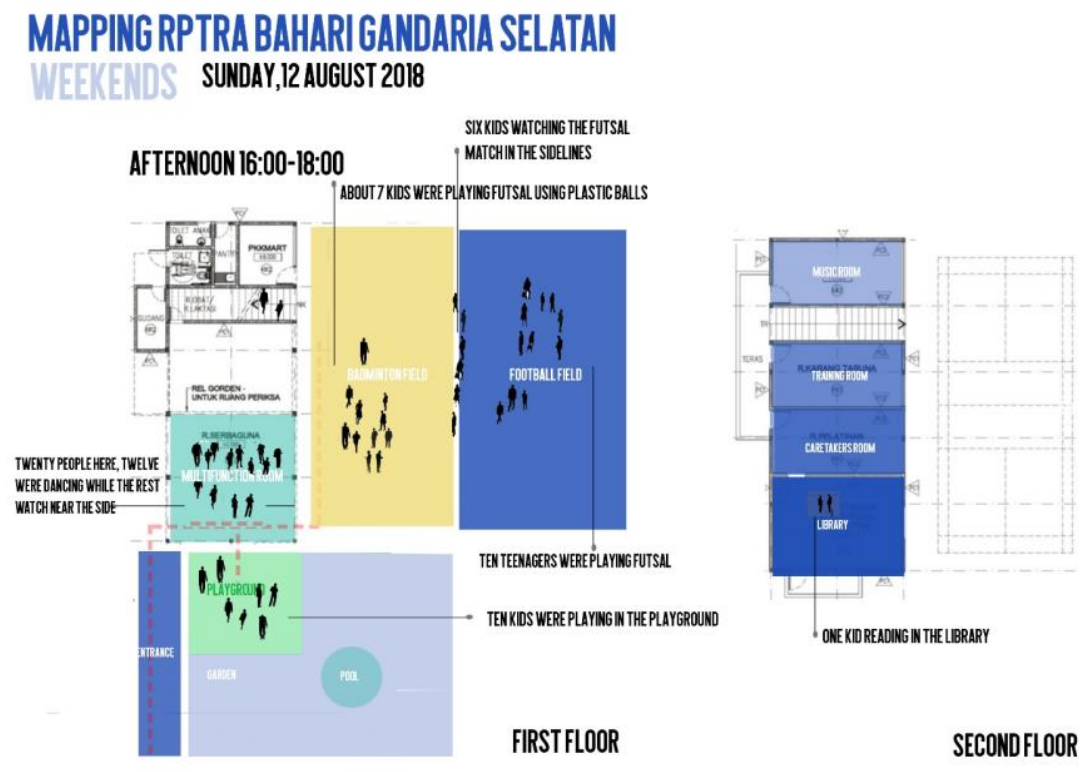

Figure 7 Mapping RPTRA weekend afternoon (Author, 2018) 
As the sun sets, the activities in RPTRA slowly disappear and children go home to study. Apart from observing the everyday uses of RPTRA, we also mapped the visitors to investigate who they are and how frequently they use the RPTRA. The results show that the children who visit the RPTRA are from a $500 \mathrm{~m}$ radius, while teenagers are a majority from a $3 \mathrm{~km}$ radius. Some of them use the RPTRA to playing mini soccer, taekwondo, and dance while others simply enjoy the public space. Interestingly, the adult visitors are mostly from a $500 \mathrm{~m}$ radius, mainly because they accompany their children. Other adults come from the surrounding neighbourhoods for activities such as aerobics or social gatherings. The place's sense of belonging is shown through the constant activities and people coming from the surrounding neighbourhood. Based on this observation, it can be concluded that people are enthused to use this child-friendly community centre for their daily activities (Elyda \& Budiari, 2015).

\section{Conclusion}

Jakarta long has been suffering from heavy top down approach in terms of building public places (Kusno, 2000) (Dovey, 2010). Political representation in RPTRA Bahari is portrayed through the inclusion of public participation in the process of designing and building RPTRA. Even though public participation is limited, at the tokenism level, according to Arnstein ladder of participation, this model of making Jakarta public space is claimed to be the first innovation during the Ahok era. The new approach of making public space can be seen as new way of representing the power through urban form. While Ahok is notorius as iron-hand governor in using his authority to evict people from the illegal settlements, RPTRA shows his dichotomy approach toward the city. Allowing people's participation can be seen as a democratic way of making urban space.

Through the analysis of everyday uses, the political representation is unravelled. Even though it is not entirely open for public, the RPTRA Bahari allows citizens to have activities. The participative design approach implemented on the site shows that people are continuously using this space based on their preferences that were indicated during the early development stage. The design process allows input from the community and the facility's development involves public participation. Placing community as the subject made this place a successful urban project. Based on these findings, the participative design approach allowed dialogue between the authorities and the community and is a good model for designing public spaces. The way they use the space allows negotiation between users. Everyone has the same right to the city, even though those rights are limited to a certain period.

\section{References}

Alsayyad, N. (1992). Forms of Dominance: On the Architecture and Urbanism of the Colonial Enterprise. Avebury: Aldershot.
Arendt, H. (1998). The Human Condition. London: The University of Chicago Press.

Arnstein, S. R. (1969). A Ladder of Citizen Participation. Journal of The American Planning Association. 35(4): 216-224.

Carina, J., 2017. DKI Akui RPTRA Hasil CSR Lebih Flexible Dalam Perubahan Desain. Kompas, 28 July.

Carr, S., Francis, M., L.G, R., \& Stone, A. (1992). Public Space. New York: Cambridge University Press.

Dede, O. M., 2012. A New Approach For Participative Urban Design: An Urban Design Study Of Cumhuriyet Urban Square in Yozgat Turkey. Journal of Geography and Regional Planning .5: 122-131.

Desrianto, M., 2018. Bangun 7 Taman Maju Bersama, Pemrov DKI Ingin Perkuat Interaksi Warga. megapolitan.kompas.com, 11 December.

Dovey, K., 2010. Becoming Places. New York: london.

Elyda, C., \& Budiari, I. (2015, September 17). Jakartans Enthused with New RPTRA Community Centers. The Jakarta Post.

Gehl, J. (1987). Life Between Building (Using Public Space). London: Island Press.

Hernowo, E. \&. N. A., 2017. Karakteristik Ruang Publik Terpadu Ramah Anak (RPTRA) Bahari di Kecamatan Cilandak Jakarta Selatan. Jurnal Teknik. 6(2): 2337-3520.

H. S. Aji, R. B. (2016). The Development Of Child-Friendly Integrated Public Space In Settlement Areas As An Infrastructure of Jakarta. In C. Brebbia, WIT Transaction on Ecology and the Environment (p. 13). USA: WIT Press.

Iveson, K. (2007). Publics and the City. Wiley: Kindle Edition.

Kahraman, M., Pak, B., \& Scheerlinck, K. (March 2018). Production of Heterotopias as Public Spaces and Paradox of Political Representation: A Lefebvrian Approach. ITU AZ Journal, 135-145. http: / / www. azitujournal.com/jvi.aspx?pdir=itujfa\&plng=eng\&un=IT UJFA-58569

Kusno, A., 2000. Behind the Postcolonial: Architecture, Urban Space and Political Cultures in Indonesia. 1st edition ed. London: Routledge.

Laksana, B. A., 2017. M. Taufik Minta Pembangunan RPTRA yang Pakai Dana CSR diaudit. Detiknews.com, 29 Mei.

Lefebvre, H. (1996). Writing on Cities. Oxford: Blackwell Publisher.

Mamduh, N., 2018. Pemprov DKI akan Hapus Anggaran Pembangunan RPTRA di 2019. Tirto.id, 5 March.

Mitchell, D. (2003). The Right to the City: Social Justice and the Fight for Public Space. New York and London: Guilford Press.

Pak, B. (2017). Strategies and Tools in Bottom-up Practices in Architecture and Urban Design Studios. Knowledge Cultures. 12.

Permanasari, E., 2010. Constructing and Deconstructing the Nation: Sukarno's Monuments and Public Places in Jakarta. Germany: LAP Lambert Publishing. 
Permanasari, E., in Dovey, K. (2010). New order: Monas and Merdeka Square. In: K. Dovey, ed. Becoming Places": Urbanism / Architecture / Identity / Power. London: Routledge.

Permanasari, E., Nurhidayah, F. \& Nugraha, H., 2018. Metode Desain Partisipatif Sebagai Model Pembangunan 6 RPTRA DKI Jakarta. Jakarta: Universitas Pembangunan Jaya.

Sanders, Elizabeth B-N; SonicRim. (2002). From User-Centered to Partisipatory Design Approach. In J. Frascara, Design and Social Sciences: Making Connections. London And New York: taylor and Francis.
Tonnelat, S., 2010. The Sociology of urban Public Spaces. In: Territorial Evolution and Planning Solution: Experience from China and France. Paris: Atlantis Press. 1-10.

Vale, L., 1992. Architecture, Power and National Identity. London: Yale University Press.

Zeisel, J. (2006). Inquiry by Design. California: Cambridge University Press. 